Research Article

\title{
Calculation of Pile Side Friction by Multiparameter Statistical Analysis
}

\author{
Zhijun Zhou $\mathbb{D},{ }^{1}$ Yaqin Dong, ${ }^{1}$ Peijun Jiang, ${ }^{1}$ Dandan Han, ${ }^{1}$ and Tong Liu $\mathbb{D}^{2}$ \\ ${ }^{1}$ School of Highway, Chang'an University, Xi'an, Shaanxi 710064, China \\ ${ }^{2}$ School of Science, Xi'an University of Architecture and Technology, Xi'an, Shaanxi 710055, China \\ Correspondence should be addressed to Tong Liu; liutong@xauat.edu.cn
}

Received 10 February 2019; Revised 13 May 2019; Accepted 3 June 2019; Published 18 June 2019

Academic Editor: Zaobao Liu

Copyright (c) 2019 Zhijun Zhou et al. This is an open access article distributed under the Creative Commons Attribution License, which permits unrestricted use, distribution, and reproduction in any medium, provided the original work is properly cited.

In this paper, a static load test and a multiparameter statistical analysis method are used to study the value of pile side friction in different soil layers in a loess region. Currently, static load testing is the most commonly used method to determine the bearing capacity of pile foundation. During the test, a vertical load is applied at the top of the pile, the data under each load level are recorded, and a Q-S curve is drawn to obtain the ultimate bearing capacity of a single pile. Reinforcement stress gauges are installed at different sections of the pile body, and then the axial force and the pile side friction of each section are calculated. Few studies have investigated the calculation of pile side friction in different soil layers using the multiparameter statistical analysis method. Obtaining accurate results using this method will provide an important supplement to the calculation of pile side friction and will also be conducive to the development of theoretical calculation of pile side friction. Therefore, taking Wuding Expressway project in loess region as an example, the lateral friction resistance of six test piles is studied through static load testing and multiparameter statistical analysis. The multiparameter statistical analysis method is compared with the static load test results, and the error is controlled within $20 \%$. The results show that the calculation results of multiparameter statistical analysis essentially fulfill engineering requirements.

\section{Introduction}

Loess sediment covers a large part of the globe, accounting for one-tenth of the land area worldwide. Loess is prevalent in China, with complete strata and heavy thickness, covering an area of approximately $630,000 \mathrm{~km}^{2}[1,2]$. Loess is a yellow silt sediment which was mainly transported by wind during the Quaternary period. It is rich in carbonate, with large voids, obvious vertical joints, and generally low groundwater level $[3,4]$. With the continuous development of China's economy, the traffic in loess areas is developing rapidly, along with increased construction of large highways and bridges [5-10].

At present, pile foundation is the most commonly used foundation form in highway bridge construction, and it is a durable and effective infrastructure [11-15]. In the loess region of Shaanxi Province, bored cast-in-place piles are widely used due to their well-developed construction technology and high bearing capacity [16-21]. Most of the piles are $30-70 \mathrm{~m}$ in length and more than $1 \mathrm{~m}$ in diameter. Friction piles or end-bearing friction piles are also commonly used. For long piles, the frictional resistance of the pile side accounts for more than $80 \%$ of the bearing capacity of piles, and for short piles, the resistance generally accounts for more than $60 \%$ [22-26]. Therefore, the calculation of lateral resistance in loess areas is of great significance to the construction of highway bridges in such areas of China $[27,28]$.

At present, the static load test method is one of the most widely used techniques to determine pile side friction [29-31]. A large amount of research into static load testing has been carried out. Static load testing of two $0.45 \mathrm{~m}$ thick steel pipe piles to analyze the pile side friction distribution law suggested that the effective stress method could be used to express frictional resistance around piles [32]. Based on the static load test of two concrete-driven piles, a formula for calculating the pile side friction of cohesive soil and remolded soil was also proposed [33]. Through static load 
testing of large diameter and superlong piles in a soft soil area around Dongting Lake, it was found that the piles showed obvious characteristics of friction piles, and a formula for calculating the lateral load transfer model of linear elastic-fully plastic piles was presented [34]. Static load testing of large diameter and superlong bored piles in soft soil areas was undertaken to analyze the load transfer law and bearing characteristics of these piles, and the relative displacement of piles and soils when the pile side friction of different soil layers reached the limit value was presented [35]. Through static load testing of an end-bearing pile, it was concluded that pile side friction affected the bearing capacity of the end-bearing pile to a certain extent, and the bearing capacity exceeded the design bearing capacity of a single pile [36]. The relationship between the total lateral resistance of piles and the settlement at the end of piles under different bearing levels was obtained by static load testing of bored cast-in-place piles, which indicated that the total lateral resistance of piles could be increased by increasing the strength of rock or soil at the end of piles [37]. Field load tests on superlong cast-in-situ piles were also carried out, and the axial force curves of test piles under different load levels were obtained, as well as the relationship between unit friction and relative displacement of pile and soil. Through this experiment, it was shown that the unit frictional resistance under compressive load could be calculated by dividing the difference of two continuous axial forces by the area of the pile body between strain gauges [38].

The multiparameter statistical analysis method collects data from many test piles and establishes the relationship between pile side friction, cohesion, and the internal friction angle of the soil layer [39, 40]. However, few studies have been carried out to calculate pile side friction by the multiparameter statistical analysis method. Therefore, taking Wuding Highway in the Loess Plateau as an example, this paper carries out static load tests on six test piles and measures the size and distribution of pile side friction. The pile side friction in different soil layers is then calculated using the multiparameter statistical analysis method. Finally, the two results are compared. Obtaining a reasonable result using this method will provide an important supplement to the calculation of pile side friction, and it will also be conducive to the development of theoretical calculation of pile side friction.

\section{Test Site Engineering}

Wuding Expressway is located within Yan'an City and Yulin City in Shaanxi Province, China (Figure 1). It starts from the east of Wuqi County, ends at Shijingzi, Southeast of Dingbian County, and is approximately $922.17 \mathrm{~km}$ long. The abutments on both sides are located in the Loess Lianghe subarea, and the topography of the abutment area is relatively small. The elevation of the ground level is between $1629.60 \mathrm{~m}$ and $1644.59 \mathrm{~m}$, and the relative elevation difference is approximately $14.99 \mathrm{~m}$. The test site shown in Figure 1 is situated at the separated intersection of Sunkelan Village, Yangjing Town, and Dingbian County. The topographic fluctuation of the test site is small, there is no surface water, the groundwater is very deep, and no groundwater is present in the process of drilling. The strata of the test site consist of the following:

(1) Loessial soil $\left(Q_{4}^{\mathrm{pl}}\right)$ : the soil is brown-yellow, relatively uniform, contains macropore, wormhole, plant rhizome, and a small amount of gravel and hard plastic.

(2) Old loess $\left(Q_{2}^{\text {eol }}\right)$ : the soil is brown and yellow and relatively noncomplex. A small amount of hyphae is present in the soil, accompanied by wormholes, pinholes, some shellfish, and hard plastic.

\section{Test Contents}

3.1. Indoor Test. Laboratory testing of soils in the test area was mainly comprised of a moisture content test (Figure 2(a)), a compression test (Figure 2(b)), and a direct shear test (Figure 2(c)). The drying method was used in the soil moisture content test, and the soil void ratio was obtained by the compression test. Through analyzing the data from the moisture content and compression tests, the stratum characteristics and the main physical properties of the soil layer in the test area were obtained, as shown in Table 1.

Cohesion and internal friction angle are important parameters used in this paper. Therefore, 34 groups of samples were tested by the direct shear test, including eight groups of loessial soil samples and 26 groups of old loess samples. In the direct shear test, the upper and lower boxes were aligned, fixed pins were inserted, and the pervious stones and filter paper were placed in the lower boxes. The knife edges of the ring knife with samples were placed upward, the knife back was downward, and the cutting box mouth aligned. The filter paper and the upper pervious stones were then placed, and the samples were pushed into the shear box slowly. Following this, the ring knife was removed, and the force transfer cover plate was added. Sliding steel balls were then installed, along with the shear box and force measuring ring. A preload of 0.01 was applied, the handwheel was rotated, and the dial reading of the force measuring ring was zeroed. After applying the vertical pressure, the fixed pin was pulled out immediately, the stopwatch was commenced, and the handwheel was rotated at a uniform speed of $0.8 \mathrm{~mm} / \mathrm{min}$ (shear displacement was $0.2 \mathrm{~mm}$ per rotation cycle) so that the specimen was sheared and destroyed within 3-5 min. With every turn of the handwheel, the scale reading in the measuring ring was recorded once until soil sample shear failure. The calculated cohesive force and internal friction angle are provided in Table 2.

3.2. Static Load Test. For the static load test, the anchor piles and test piles were arranged in the form of four anchor piles surrounding one test pile. The spacing between the anchor pile and test pile is illustrated in Figure 3. Six test piles with a diameter of $1.5 \mathrm{~m}$ and length of $25 \mathrm{~m}$ were set up in the test area, along with anchor piles with a diameter of $1.5 \mathrm{~m}$ and length of $30 \mathrm{~m}$. The pile body was constructed with C30 concrete, and C40 concrete was used 


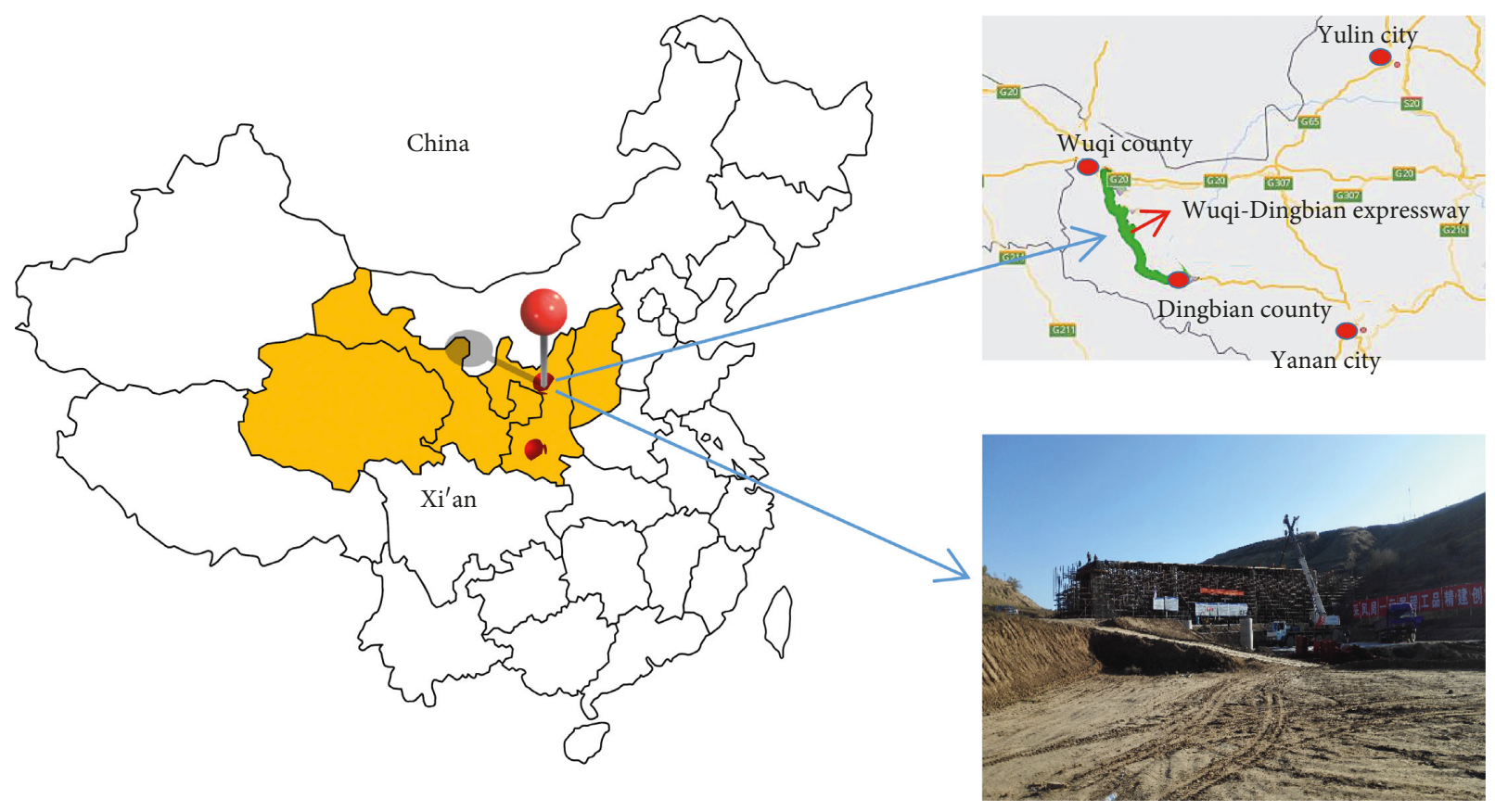

Loess area

FIgURE 1: The approximate location of the test area (map data (c) 2018 Baidu maps; loess area distribution ( $)$ Baidu encyclopedia; the picture was taken by Zhijun Zhou).

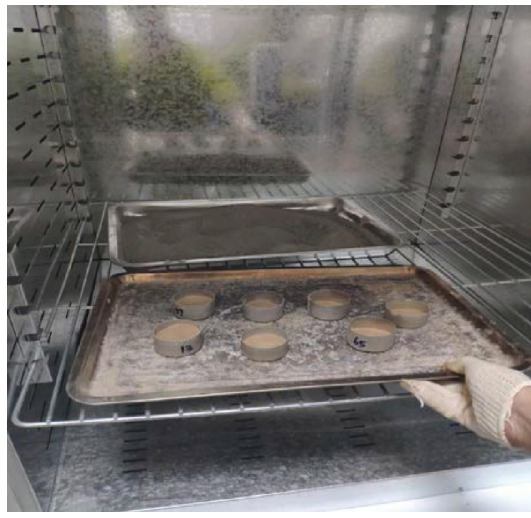

(a)

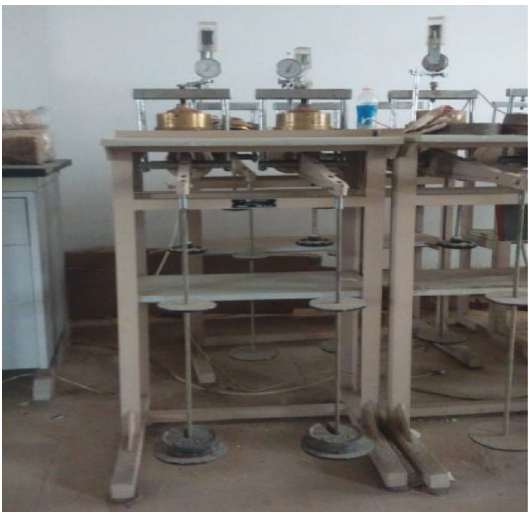

(b)

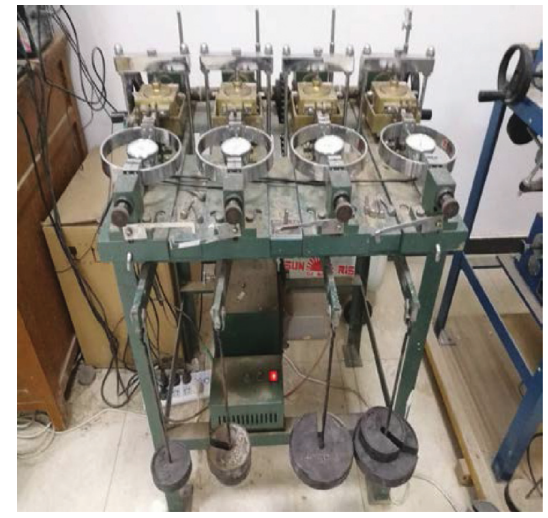

(c)

Figure 2: Indoor tests. (a) Moisture content test. (b) Compression test. (c) Direct shear test.

TABLE 1: Stratigraphic characteristics and physical indicators in experimental area.

\begin{tabular}{lccccccc}
\hline $\begin{array}{l}\text { Soil layer } \\
\text { division }\end{array}$ & Depth $(\mathrm{m})$ & $\begin{array}{c}\text { Layer } \\
\text { thickness }(\mathrm{m})\end{array}$ & $\begin{array}{c}\text { Density } \\
\left(\mathrm{g} / \mathrm{cm}^{3}\right)\end{array}$ & $\begin{array}{c}\text { Water } \\
\text { content } w(\%)\end{array}$ & $\begin{array}{c}\text { Void } \\
\text { ratio } e\end{array}$ & $\begin{array}{c}\text { Liquid } \\
\text { index } I_{\mathrm{L}}\end{array}$ & $\begin{array}{c}\text { Compression } \\
\text { coefficient } a_{1-2}\left(\mathrm{MPa}^{-1}\right)\end{array}$ \\
\hline $\begin{array}{l}\text { Loessial soil }\left(Q_{4}^{\mathrm{pl}}\right) \\
\text { Old loess }\left(Q_{2}^{\mathrm{eol}}\right)\end{array}$ & $0 \sim 6.5$ & $1.8 \sim 6.5$ & 1.68 & 16.3 & 0.883 & 0.37 & 0.35 \\
\hline
\end{tabular}

to reinforce the part $1.5 \mathrm{~m}$ away from the top of the pile. According to preliminary field investigation data, the groundwater in this area is deeply buried and there is no surface water. The dry rotary drilling method was thus used to drill test piles and anchor piles. After checking the quality of the hole, the reinforcement cage skeleton was lifted and the piles were poured into the pile. The entire testing process consisted of three parts: installation and layout of test elements before the test, construction of the test piles and anchor piles, and test loading and data collection. The specific process for each relevant component is detailed as follows: 
TABLE 2: Shear strength parameters.

\begin{tabular}{|c|c|c|c|c|c|c|c|}
\hline \multirow{2}{*}{ Soil layer division } & \multirow{2}{*}{ Number of samples } & \multicolumn{3}{|c|}{ Cohesive force $c(\mathrm{kPa})$} & \multicolumn{3}{|c|}{ Internal friction angle $\phi\left(^{\circ}\right)$} \\
\hline & & Maximum & Minimum & Average & Maximum & Minimum & Average \\
\hline Loessial soil $\left(Q_{4}^{\mathrm{pl}}\right)$ & 8 & 8.3 & 5.4 & 6.8 & 29.4 & 25.9 & 28.4 \\
\hline Old loess $\left(Q_{2}^{\text {eol }}\right)$ & 26 & 43.0 & 11.8 & 30.5 & 32.9 & 18.6 & 25.8 \\
\hline
\end{tabular}

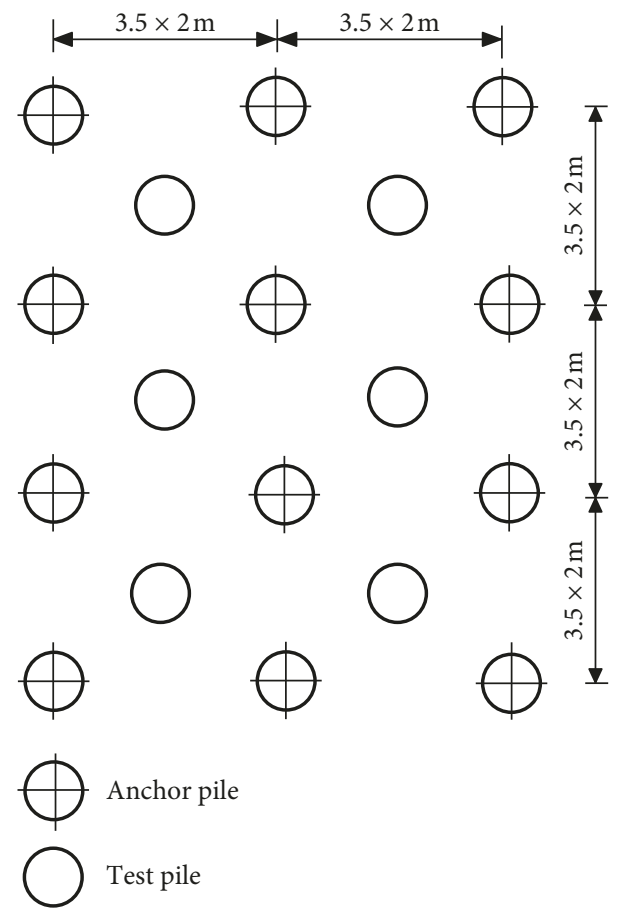

FIgURE 3: Layout of anchor piles and test piles.

(1) According to the test requirements, it was necessary to measure the axial force and lateral resistance of the pile under various loads during the test process. Therefore, before the construction of the anchor piles and test piles, a certain number of reinforcement stress gauges were embedded in the pile. Considering the integrity of the test data collection, seven sections were selected along the main reinforcement in the pile for reinforcement stress gauge placement. Because the upper part of the pile was in direct contact with the jack when loading, the deformation was large, so the first layer of the stress gauge meter was placed $0.5 \mathrm{~m}$ below the pile top, and the laying depth was $3.5 \mathrm{~m}, 6.5 \mathrm{~m}, 11 \mathrm{~m}, 15.5 \mathrm{~m}, 20 \mathrm{~m}$, and $24.5 \mathrm{~m}$ in turn (Figure 4), with each section connected to three reinforcement stress gauges. The stress gauges at the bottom $24.5 \mathrm{~m}$ were located at the end of the test pile and were used to measure the internal force at the bottom of the pile and the resistance at the end of the pile. The reinforcement stress gauges in the middle part measured the internal force of the pile at each soil layer and at the boundary of the soil layer. In the past, reinforcement stress gauges have been welded directly in series to the main reinforcement in the pile. However, high temperatures produced during welding can easily damage the reinforcement stress

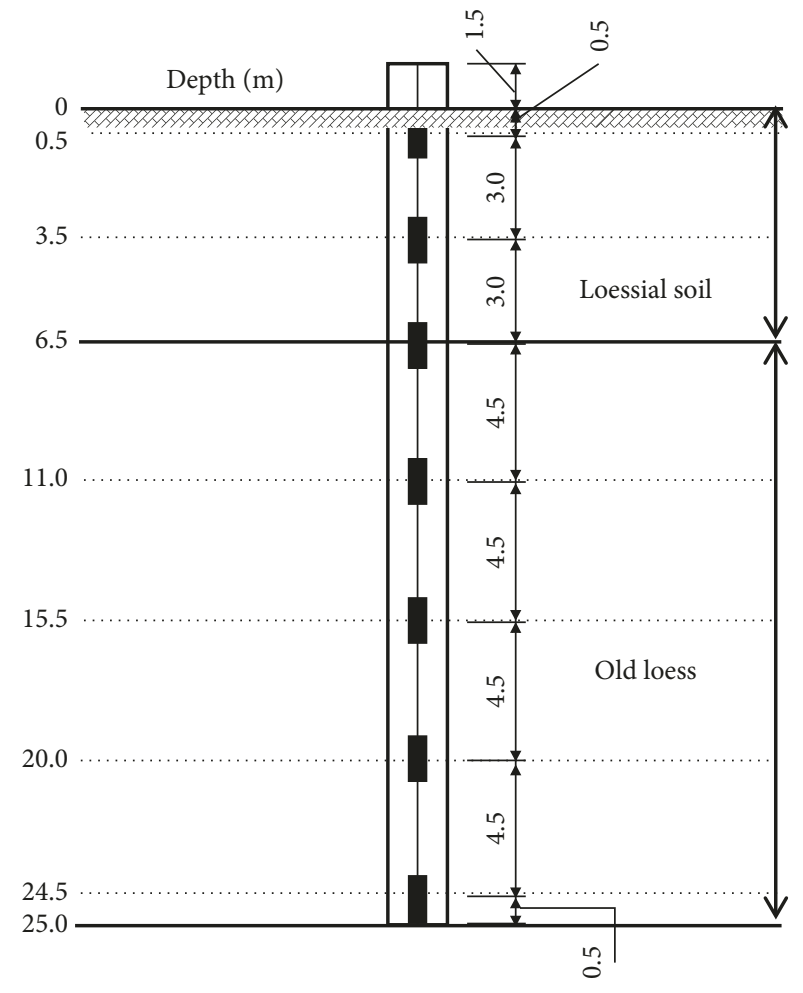

FIGURE 4: Layout of the stress gauges.

gauge, thus affecting the test results. Therefore, damage to the steel bars must be avoided when laying out the steel bars, to avoid the stress gauges being affected. In this experiment, the reinforcement connecting the two ends of the stress gauge was processed, and then the high-strength carbon steel cylinder nuts at the two ends of the stress gauge were connected with the reinforcement to protect the reinforcement stress gauge, and it was ensured whether it was able to collect the relevant data easily.

(2) With the development of machinery and equipment, rotary drilling bored piles are often used in the construction of pile foundations (friction piles) in loess areas. Compared with manual drilling and percussive drilling, rotary drilling has positive characteristics including high drilling efficiency, with an average drilling rate of $10 \mathrm{~m} / \mathrm{h}$. If the groundwater level in the loess area is relatively low, dry drilling can be used to prevent the loess layer around the pile from losing strength or increasing gravity when it encounters water. Rotary drilling construction in loess areas does not require the construction of mud wall protection as the rotary drilling bit will produce mud in the process of drilling which will keep the 
hole wall stable and perform hole-forming wall protection. Compared with impact drilling, rotary drilling has less effect on soil compaction on the hole side. In rotary drilling, the bit moves back and forth on the bottom of the hole and the ground, which makes the hole wall rougher. Higher roughness of soil around the rotary excavation pile can better reflect the interaction between pile and soil.

According to Chinese code [41], when bored by rotary drilling in dry operation (Figure 5(a)), the thickness of bottom sediment of friction piles with diameter less than $1.5 \mathrm{~mm}$ should be less than $300 \mathrm{~mm}$, and the inclination of pile holes should not be less than 1\%; the diameter should not be less than the design value of the pile diameter; and the hole depth should not be less than the design stipulation. Thus, after checking the quality of hole-forming meets the requirements, the steel cage skeleton was hoisted (Figure 5(b)) and poured into piles (Figure 5(c)). In the process of drilling holes by rotary drilling, the protecting barrel is used. The protecting barrel is raised $1.5 \mathrm{~m}$ above the ground in the concrete filling process of each test pile. After the completion of concrete filling, the protecting barrel of each test pile is not pulled out for later loading so as to prevent the upper concrete from being damaged by compression due to large load in the loading process.

(3) The static load test was carried out using an anchor pile reaction device, as illustrated in Figure 6(a). Firstly, eight hydraulic jacks (Figure 6(b)) were evenly arranged on the steel cushion box with sufficient strength and stiffness, and then the main beam and the secondary beam (Figure 6(c)) were hoisted, respectively, with the middle of the main beam located on the hydraulic jack as far as possible. When the secondary beam was hoisted, it was necessary to ensure that the two ends of the secondary beam were in accordance with the position of the anchor pile. After the datum beam was set in place, the displacement dial gauge (Figure 6(d)) was installed on the steel sheet with a magnetic meter frame, and the settlement of the pile top was measured in real time.

Loading was carried out by the slow-speed method. For this experiment, single stage loading was $1,000 \mathrm{kN}$, the maximum load was $12,000 \mathrm{kN}$, and the loading stage was 11. According to Chinese code [42], when the variation of settlement in one hour is less than $0.1 \mathrm{~mm}$ under the action of various loads and occurs repeatedly, the settlement of the test pile can be considered to be relatively stable. When the pile is in the process of testing, loading can be stopped when one of the following conditions occurs [42]: (1) when the settlement of the pile top under the load is more than five times that under the previous load, the total settlement of pile top is more than $40 \mathrm{~mm}$ and (2) when the maximum loading value required by the design has been reached, the pile top settlement has reached a relatively stable standard.
In this study, the unloading load of the test pile was twice that of the graded load when the loading process was completed, and the unloading load lasted for one hour at each stage. At the same time, the settlement at the top of the pile and the bar gauge were measured. After the unloading process was complete, the residual settlement was measured over three hours.

\section{Static Load Test Result Analysis}

4.1. Settlement Calculation of Pile Top. The bearing capacity of multiple test piles of the same test site engineering and same size was varied, and the average value was taken to carry out static load test result analysis [39, 40]. Four displacement meters were installed to measure the settlement of the pile top under different loads in real time, and then the average settlement of four pile tops was taken as the settlement of the pile top under different loads.

The calculation results are provided in Table 3. The Q-S curve is formulated by calculating the settlement value of the pile top. The Q-S curve is an intuitive manifestation of the loading process of pile static load testing, as shown in Figure 7. Analysis of Figure 7 shows that the settlement of the test pile increases suddenly during the loading process. The Q-S curve shows a sharp drop point, which can illustrate the ultimate bearing capacity of the pile. The ultimate bearing capacity of the test pile is $9,000 \mathrm{kN}$.

4.2. Axial Force of Pile Body Calculation. When calculating the axial force of the pile body, it is assumed that the pile body is of equal cross section and that the pile body is made of linear elastic material. Under the action of the arbitrary first-order load, the stress of each section of the pile can be obtained by measuring the frequency value of the stress gauges in the main reinforcement and calculating the stress value $[27,43,44]$ by using the relevant formula. Then the strain value of the pile body at each section can be obtained by using the relevant formula. The axial force of the steel bar at each section of the pile body can be determined according to the following formula:

$$
p_{\mathrm{si}}=K\left(F_{i}^{2}-F_{0}^{2}\right)+B
$$

where $p_{\mathrm{si}}$ is the axial force of the steel bars, $K$ is the calibration coefficient, $F_{i}$ is the vibration frequency of the steel string at section $i$ under the load, $F_{0}$ is the initial vibration frequency of the steel string, and $B$ is the calculated correction value, which is 0 in this paper. The strain values of the corresponding sections are given by using the following formula:

$$
\varepsilon_{\mathrm{si}}=\frac{p_{\mathrm{si}}}{E_{\mathrm{s}} A_{\mathrm{s}}},
$$

where $\varepsilon_{\mathrm{si}}$ is the strain of the steel bar and $E_{\mathrm{s}}$ is the elastic modulus of steel bar, which is $200 \mathrm{GPa}$ in this test. Additionally, $A_{\mathrm{s}}$ is the section area of the steel bar, which is $0.0004909 \mathrm{~m}^{2}$. In the process of calculation, if the deformation of concrete and steel bars is assumed to be in 


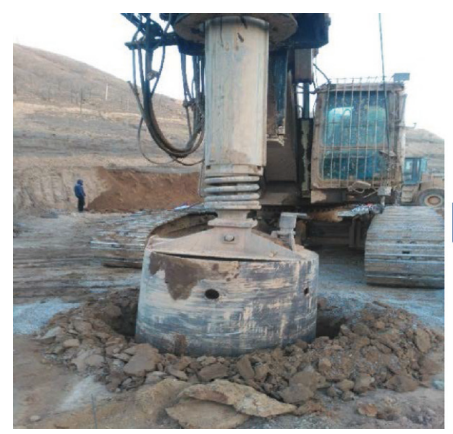

(a)

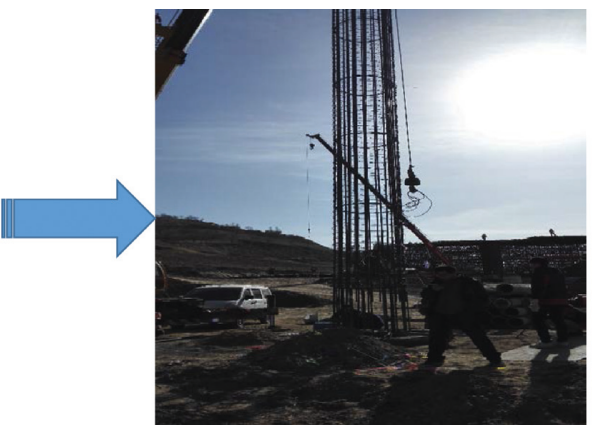

(b)

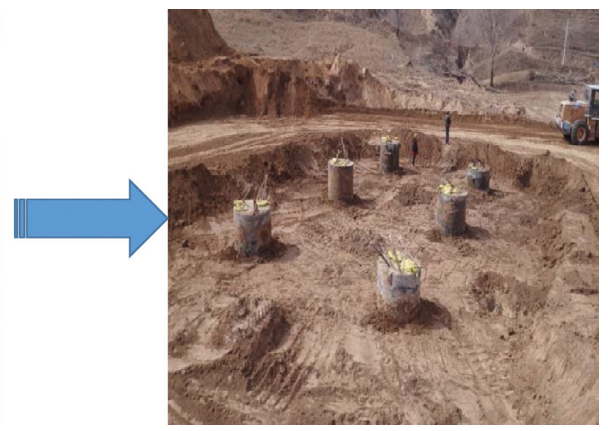

(c)

Figure 5: Construction of test piles and anchor piles. (a) Rotary drilling. (b) Lifting steel cage. (c) Test pile forming.

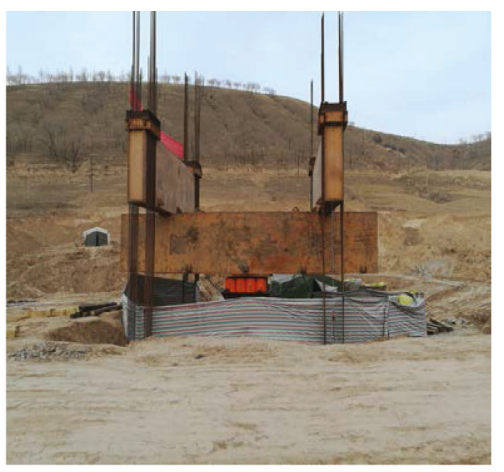

(a)

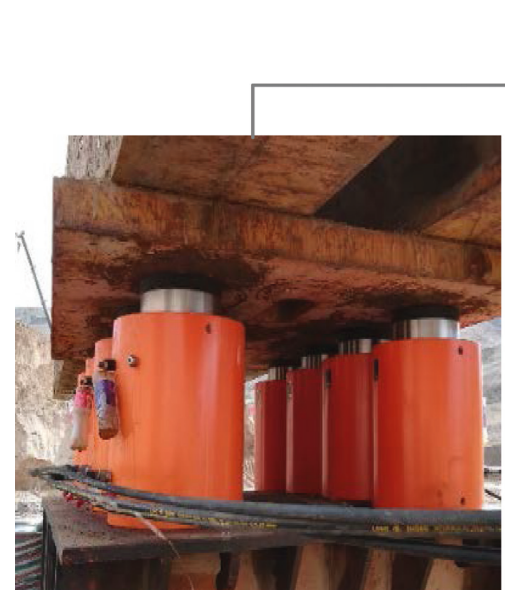

(b)

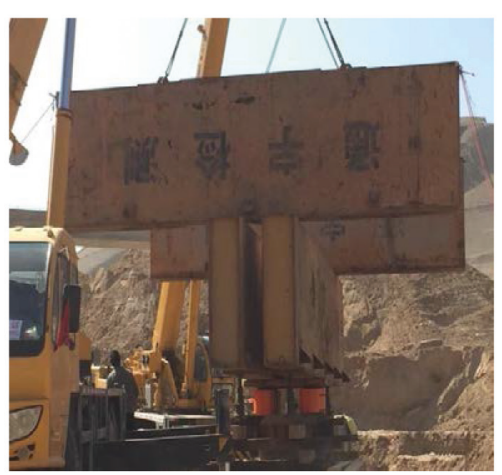

(c)

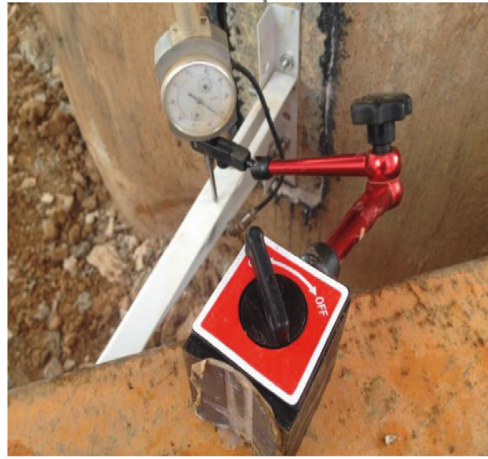

(d)

Figure 6: Loading device. (a) Anchor pile reaction device. (b) Eight hydraulic jacks. (c) The main beam and the secondary beam. (d) The displacement dial gauge.

TABLE 3: Average settlement value of the test pile.

\begin{tabular}{lccccc}
\hline $\begin{array}{l}\text { Serial } \\
\text { number }\end{array}$ & $\begin{array}{c}\text { Load } \\
(\mathrm{kN})\end{array}$ & $\begin{array}{c}\text { Loading time }(\mathrm{min}) \\
\text { Accumulated time } \\
(\mathrm{min})\end{array}$ & $\begin{array}{c}\text { Settlement at this level } \\
(\mathrm{mm})\end{array}$ & $\begin{array}{c}\text { Settlement }(\mathrm{mm}) \\
\text { Accumulated settlement } \\
(\mathrm{mm})\end{array}$ \\
\hline 1 & 2,000 & 120 & 120 & 0.2050 & 0.2050 \\
2 & 3,000 & 120 & 240 & 0.3625 & 0.5675 \\
3 & 4,000 & 120 & 360 & 0.3800 & 0.9475 \\
4 & 5,000 & 120 & 480 & 0.4375 & 1.3850 \\
5 & 6,000 & 120 & 600 & 0.0700 & 1.4550 \\
\hline
\end{tabular}


TABLE 3: Continued.

\begin{tabular}{lccccc}
\hline $\begin{array}{l}\text { Serial } \\
\text { number }\end{array}$ & $\begin{array}{c}\text { Load } \\
(\mathrm{kN})\end{array}$ & $\begin{array}{c}\text { Loading time }(\mathrm{min}) \\
\text { Accumulated time } \\
(\mathrm{min})\end{array}$ & $\begin{array}{c}\text { Settlement at this level } \\
(\mathrm{mm})\end{array}$ & $\begin{array}{c}\text { Settlement }(\mathrm{mm}) \\
\text { Accumulated settlement } \\
(\mathrm{mm})\end{array}$ \\
\hline 6 & 7,000 & 150 & 750 & 0.8325 & 2.2875 \\
7 & 8,000 & 150 & 900 & 1.1550 & 3.4425 \\
8 & 9,000 & 150 & 1050 & 3.7850 & 7.2275 \\
9 & 10,000 & 150 & 1200 & 14.7425 & 21.9700 \\
10 & 11,000 & 120 & 1320 & 20.7725 & 42.7425 \\
11 & 12,000 & 150 & 1470 & 30.1241 & 72.8666 \\
\hline
\end{tabular}

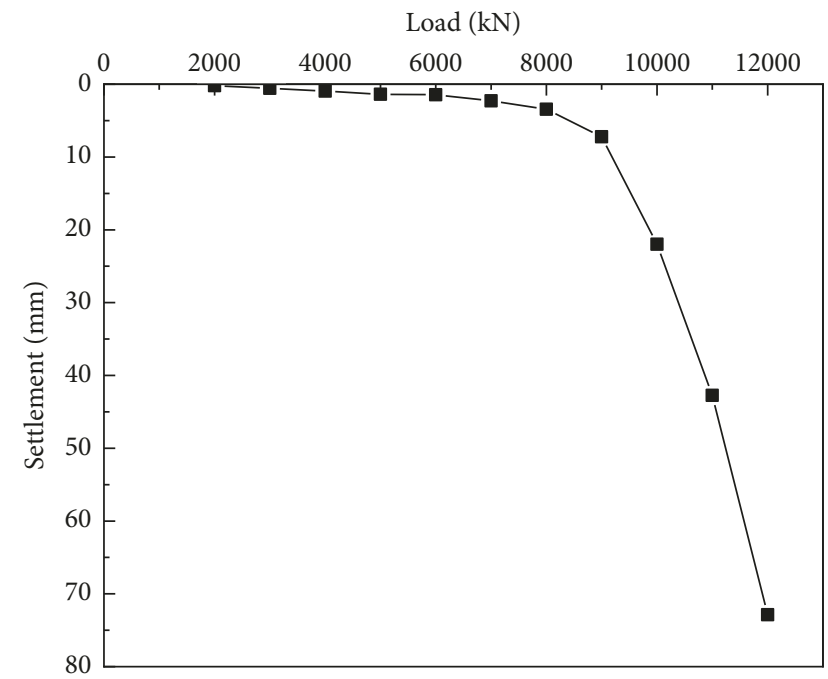

Figure 7: The Q-S curve of the test pile.

harmony with each other, the axial force of the pile at the section can be obtained as follows:

$$
Q_{i}=\left(E_{\mathrm{s}} A_{\mathrm{s}}+E_{\mathrm{c}} A_{\mathrm{c}}\right) \varepsilon_{\mathrm{si}} \text {, }
$$

where $Q_{i}$ is the axial force of the pile body at section $i$ and $E_{c}$ is the elastic modulus of concrete. As the strength grade of pile concrete is C30, according to Chinese code [45], the value of $E_{\mathrm{c}}$ in this test is $30 \mathrm{GPa}$ and $A_{\mathrm{c}}$ is the section area of concrete. Using the above formulas (1)-(3), the axial force curve of the pile body is formulated and is presented in Figure 8. Observing Figure 8, it can be seen that during the transfer process of the pile top load, the pile tip resistance is very small and increases slowly under the first five stage loads, indicating that the pile top vertical load is mainly shared by the soil around the pile, so the pile side resistance begins to play a role before pile tip resistance. As the load continues to increase, the pile tip resistance increases significantly. If the load continues to increase, the curve change of the upper part of the pile is almost parallel, indicating that the pile side friction has fully been exerted. As shown in Figure 8 , when the test pile is loaded to $9,000 \mathrm{kN}$, the pile tip resistance is $1,708 \mathrm{kN}$, and the pile tip resistance ratio is $18.98 \%$. Therefore, the pile belongs to the end-bearing friction pile [46].

4.3. Pile Side Friction Calculation. In the course of the test, the lateral friction resistance between two adjacent sections

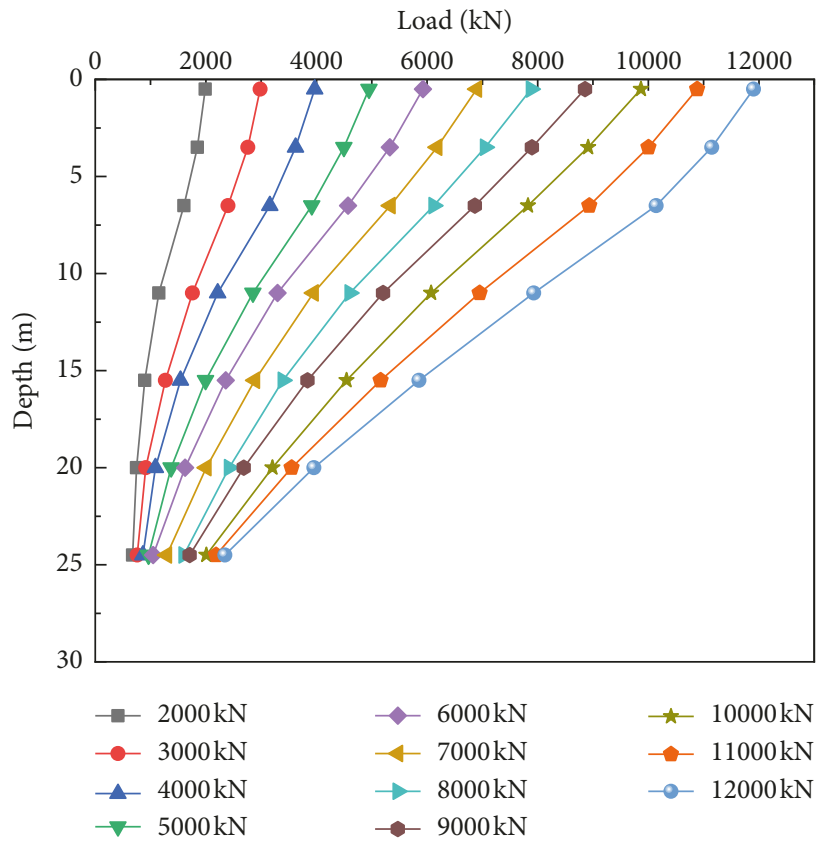

Figure 8: The axial force curve of the test pile.

can be considered approximately equal to the variation of the axial force of the pile body between the sections [27, 47-50]. Therefore, the formula for calculating the side friction resistance of the pile is as follows:

$$
q_{\mathrm{si}}=\frac{Q_{i-1}-Q_{i}}{U l_{i}}
$$

where $U$ is the perimeter of the pile body, $Q_{i-1}$ is the axial force value at section $i-1, Q_{i}$ is the axial force value at section $i$, and $l_{i}$ is the height between the upper and lower sections. The pile side friction curve is formulated and is presented in Figure 9. As shown in Figure 9, the pile side friction increases gradually in the range of $0 \mathrm{~m} \sim 11 \mathrm{~m}$, reaches peak value at $11 \mathrm{~m}$, and then decreases gradually. This is because during the load transfer process, as the depth increases, the pile side friction resistance gradually works and reaches the limit value at $11 \mathrm{~m}$. And then the pile top load begins to be mainly borne by the pile tip resistance, and the pile side frictional resistance decreases gradually.

\section{Multiparameter Statistical Analysis}

Statistical analysis methods include two kinds. The first is the trial algorithm (interpolation method), in which the 


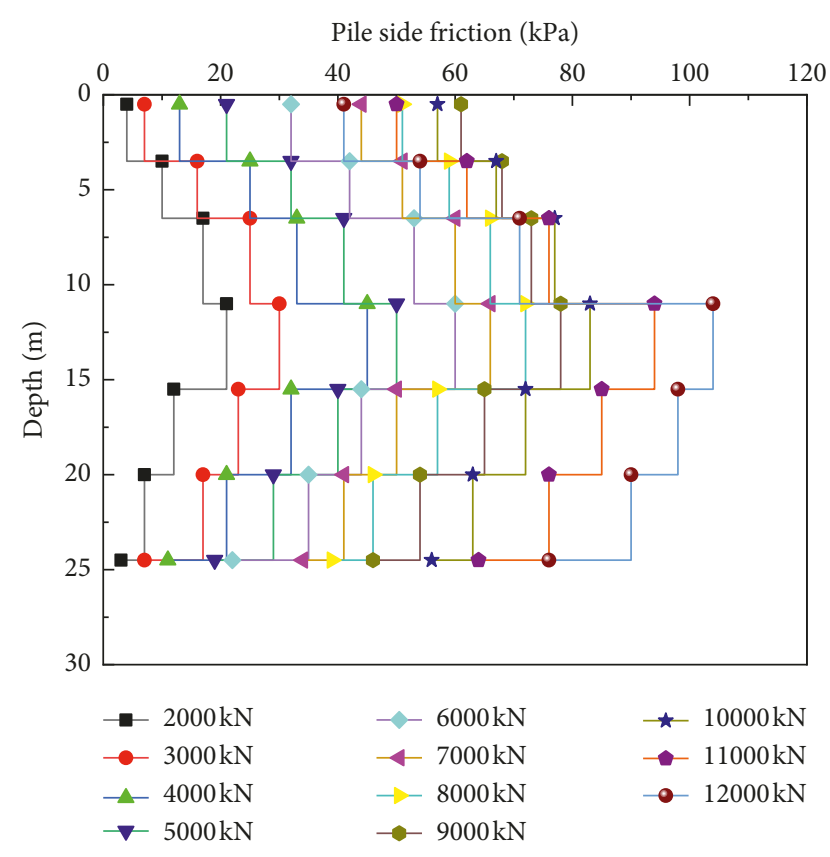

FIgURE 9: The pile side friction curve of the test pile.

maximum and minimum values given by the original code are used for trial calculation and the value of pile side friction is adjusted according to the results of the trial calculation. The existing code in China [51] adopts this trial algorithm for analysis $[40,52]$. The second method used is least squares statistical analysis, in which the number of classified soil layers with similar geological characteristics (age, stratum, and genesis) is taken as the number of unknown parameters. As the total lateral friction of each test pile can be expressed by the lateral friction of each layered soil, each test pile can be listed as an equation. When the number of test piles is equal to the number of layers, the equation system can be solved. When the number of test piles is larger than the number of layers, the least squares method can be used to simplify the equation system so that the number of equations is the same as the number of layers and the unknown value can be obtained and then substituted. The lateral friction of piles can be calculated using formula (6) [40].

5.1. Basic Equations. According to the distribution of soil layers and the total resistance of each pile which is equal to the sum of the lateral resistance of each layered soil, the lateral resistance equation of each test pile can be determined $[39,40]$ :

$$
Q_{\mathrm{f}}=U \sum_{i=1}^{m} q_{\mathrm{si}} l_{i},
$$

where $Q_{\mathrm{f}}$ is the total frictional resistance of the pile side, $U$ is the circumference of the pile, $q_{\mathrm{si}}$ is the unit surface friction resistance in the soil layer, $l_{i}$ is the pile length of each soil layer, and $m$ is the soil layer number.

According to the relationship between cohesive force, internal friction angle of shear strength index, and frictional resistance, the following equation can be formulated [40]:

$$
q_{\mathrm{si}}=b c_{i}+F_{i} \sigma_{i}^{a} \tan \phi
$$

where $a$ and $b$ are the empirical coefficients, based on existing results $[39,40], a$ and $b$ should be between 0 and $1 . \sigma_{i}$ is the average effective weight of each layer of soil, and $F_{i}$ is the empirical coefficient of pile side friction in different soil layers.

Substitute equation (6) into (5), and make

$$
\begin{aligned}
l_{i} \sigma_{i}^{a} \tan \phi_{i} & =X_{i}, \\
\frac{Q_{\mathrm{f}}}{U}-\sum_{i=1}^{m} b c_{i} l_{i} & =Y .
\end{aligned}
$$

Equation (7) can be simplified as follows [39, 40]:

$$
Y=\sum_{i=1}^{m} F_{i} X_{i}
$$

Supposing that there are $n$ test piles in the project, the soil layer is divided into $m$ layers. If $n>m$, the equation can be solved. The following formula can thus be obtained from formula (9) $[39,40]$ :

$$
\left\{\begin{array}{l}
F_{1} X_{11}+F_{2} X_{12}+\cdots+F_{m} X_{1 m}=Y_{1} \\
F_{1} X_{21}+F_{2} X_{22}+\cdots+F_{m} X_{2 m}=Y_{2}, \\
\vdots \\
F_{1} X_{m 1}+F_{2} X_{m 2}+\cdots+F_{m} X_{n m}=Y_{n}
\end{array}\right.
$$

In this paper, the principle of the least squares method is applied to the calculation of lateral friction of piles. By using the principle of the least squares method, the equations in (10) can be optimized into $m$ standard equations (13) $[39,40]$. The specific optimization process is as follows:

(1) Construct the error function

$$
\begin{aligned}
Q\left(F_{1}, F_{2}, \ldots, F_{m}\right)= & \left(F_{1} X_{11}+F_{2} X_{12}+\cdots+F_{m} X_{1 m}-Y_{1}\right)^{2} \\
& +\left(F_{1} X_{21}+F_{2} X_{22}+\cdots+F_{m} X_{2 m}-Y_{2}\right)^{2} \\
& +\cdots+\left(F_{1} X_{m 1}+F_{2} X_{m 2}+\cdots+F_{m} X_{n m}-Y_{n}\right)^{2} .
\end{aligned}
$$

(2) To minimize the error value, make

$$
\frac{\delta Q}{\delta F_{1}}=0 \quad \frac{\delta Q}{\delta F_{2}}=0 \quad \frac{\delta Q}{\delta F_{3}}=0 \quad \cdots \quad \frac{\delta Q}{\delta F_{m}}=0 .
$$

(3) The optimized standard equations are as follows:

$$
\left\{\begin{array}{l}
F_{1} \sum_{k=1}^{n} X_{k 1}^{2}+F_{2} \sum_{k=1}^{n} X_{k 1} X_{k 2}+\cdots+F_{m} \sum_{k=1}^{n} X_{k 1} X_{k m}=\sum_{k=1}^{n} X_{k 1} Y_{k}, \\
F_{1} \sum_{k=1}^{n} X_{k 2} X_{k 1}+F_{2} \sum_{k=1}^{n} X_{k 2}^{2}+\cdots+F_{m} \sum_{k=1}^{n} X_{k 2} X_{k m}=\sum_{k=1}^{n} X_{k 2} Y_{k}, \\
\vdots F_{1} \sum_{k=1}^{n} X_{m} X_{k 1}+F_{2} \sum_{k=1}^{n} X_{k m} X_{k 2}+\cdots+F_{m} \sum_{k=1}^{n} X_{k m}^{2}=\sum_{k=1}^{n} X_{k m} Y_{k} .
\end{array}\right.
$$


By solving the formulas in (13), the empirical coefficients of different soil layers $F_{i}$ can be obtained. However, two unknown empirical coefficients $a$ and $b$ remain in formula (13). According to the existing results $[39,40], a$ and $b$ are between 0 and 1 . Therefore, it is necessary to assume there are different combinations of $a$ and $b$ to obtain different combinations of $F_{i}$. Among the $F_{i}$ values of different combinations, a set of values should be chosen as the optimal solution for formula (13), so the standard deviation $\sigma$ of the formula should be calculated according to the following formula $[39,40]$. When the standard deviation $\sigma$ is the minimum, $a$ and $b$ are the most appropriate values to get the optimal solution $F_{i}[39,40]$ :

$$
\sigma=\sqrt{\frac{\sum_{k=1}^{n}\left(Y_{k}-\sum_{i=1}^{m} F_{i} X_{k i}\right)^{2}}{n-m-1}} .
$$

\section{Result Analysis of Multiparameter Statistical Analysis}

According to the basic principle of multiparameter statistics and the pile test data collected above, there are six test piles and two layers of soil on the side of the pile. Six conditional equations (15) can then be listed from formula (10):

$$
\left\{\begin{array}{l}
F_{1} X_{11}+F_{2} X_{12}=Y_{1}, \\
F_{1} X_{21}+F_{2} X_{22}=Y_{2}, \\
F_{1} X_{31}+F_{2} X_{32}=Y_{3}, \\
F_{1} X_{41}+F_{2} X_{42}=Y_{4}, \\
F_{1} X_{51}+F_{2} X_{52}=Y_{5} \\
F_{1} X_{61}+F_{2} X_{62}=Y_{6}
\end{array}\right.
$$

There are six equations and two unknown parameters in this system. The number of equations is more than the unknown number, so it can be solved by the least squares method. By using the principle of least squares, the equations in (15) can be optimized to two standard equations as follows:

$$
\left\{\begin{array}{l}
F_{1} \sum_{k=1}^{6} X_{k 1}^{2}+F_{2} \sum_{k=1}^{6} X_{k 1} X_{k 2}=\sum_{k=1}^{6} X_{k 1} Y_{k} \\
F_{1} \sum_{k=1}^{6} X_{k 2} X_{k 1}+F_{2} \sum_{k=1}^{6} X_{k 2}^{2}=\sum_{k=1}^{6} X_{k 2} Y_{k}
\end{array}\right.
$$

The equations in (16) refer to the equations of $F_{1}$ and $F_{2} . F_{1}$ and $F_{2}$ are the empirical coefficients of pile side friction in different soil layers. In the process of solving, it is necessary to assume different combinations of $a$ and $b$ to get different $F_{i}$. Their standard deviations can then be calculated according to formula (14), and the optimal solution $F_{i}$ can be determined by taking the values of $a$ and $b$ when the standard deviation $\sigma$ is the smallest. By changing combinations of $a$ and $b$, the above calculation methods for standard deviation is compiled into a MATLAB program, and the standard deviation $\sigma$ under different combinations of $a$ and $b$ is obtained, as shown in Table 4.

The results show that the minimum standard deviation is $\sigma=95.76$ when $a=0.1$ and $b=0.6$. Then, $F_{1}=31.4$ and $F_{2}=38.2$ can be obtained by solving the equations in (16). The calculated parameters are replaced by formula (6), in which the internal friction angle and cohesion of each layer of soil is averaged [40], as shown Table 2. For example, the calculated values of pile side friction at $6.5 \mathrm{~m}$ pile depth and at $24.5 \mathrm{~m}$ pile depth are as follows:

(1) Loessial soil $\left(Q_{4}^{\mathrm{pl}}\right)$ :

$$
\begin{aligned}
q_{s 1} & =0.6 c_{1}+31.4 \sigma_{1}^{0.1} \tan \phi_{1} \\
& =0.6 \times 6.8+31.4 \times 109200^{0.1} \times \tan 28.4 \\
& =58 \mathrm{kPa} .
\end{aligned}
$$

(2) Old loess $\left(Q_{2}^{\text {eol }}\right)$ :

$$
\begin{aligned}
q_{s 2} & =0.6 c_{2}+38.2 \sigma_{2}^{0.1} \tan \phi_{2} \\
& =0.6 \times 30.5+38.2 \times 442200^{0.1} \times \tan 25.8 \\
& =86 \mathrm{kPa} .
\end{aligned}
$$

Because the size of the six test piles are the same and they are located in the same project, the weighted average value of pile side friction of different soil layers under the maximum loading value $12,000 \mathrm{kN}$ in static load test is taken as the measured value, and the calculation process is as follows:

(1) Loessial soil $\left(Q_{4}^{\mathrm{pl}}\right)$ :

$$
\frac{41 \times 0.5+(41+54) \times 3 \times 0.5+(54+71) \times 3 \times 0.5}{6.5}=54 \mathrm{kPa} \text {. }
$$

(2) Old loess $\left(Q_{2}^{\text {eol }}\right)$ :

$$
\frac{(71+104) \times 4.5 \times 0.5+(104+98) \times 4.5 \times 0.5+(98+90) \times 4.5 \times 0.5+(90+76) \times 4.5 \times 0.5}{18}=91 \mathrm{kPa}
$$

Similarly, the calculation of the pile side friction resistance of each soil layer is also a weighted average. The calculated values are compared with the measured values of different soil layers in the static load test, and the error is provided in Table 5. According to Table 5, it is concluded that the error between the two methods is within $20 \%$. If the 
TABLE 4: Standard deviation under different combinations of $a$ and $b$.

\begin{tabular}{|c|c|c|c|c|c|c|c|c|c|}
\hline \multirow{2}{*}{$a$} & \multicolumn{9}{|c|}{$b$} \\
\hline & 0.1 & 0.2 & 0.3 & 0.4 & 0.5 & 0.6 & 0.7 & 0.8 & 0.9 \\
\hline 0.1 & 123.17 & 117.08 & 111.25 & 105.7 & 100.53 & 95.760 & 97.668 & 100.15 & 102.75 \\
\hline 0.2 & 124.78 & 118.71 & 112.88 & 107.33 & 102.10 & 97.26 & 100.10 & 102.63 & 105.27 \\
\hline 0.3 & 126.39 & 120.34 & 114.52 & 108.96 & 103.71 & 98.80 & 102.62 & 105.19 & 107.85 \\
\hline 0.4 & 128.01 & 121.9 & 116.18 & 110.62 & 105.33 & 100.38 & 105.22 & 107.82 & 110.50 \\
\hline 0.5 & 129.62 & 123.64 & 117.85 & 112.29 & 106.98 & 101.99 & 107.89 & 110.51 & 113.20 \\
\hline 0.6 & 131.25 & 125.30 & 119.53 & 113.97 & 108.66 & 103.63 & 110.64 & 113.26 & 115.95 \\
\hline 0.7 & 132.87 & 126.26 & 121.22 & 115.67 & 110.35 & 105.29 & 113.43 & 116.06 & 118.74 \\
\hline 0.8 & 134.50 & 128.62 & 122.90 & 117.38 & 112.07 & 106.99 & 116.29 & 118.91 & 121.57 \\
\hline 0.9 & 136.12 & 130.30 & 124.62 & 119.11 & 113.80 & 108.71 & 119.18 & 121.79 & 124.44 \\
\hline
\end{tabular}

TABLE 5: Comparison of measured and calculated values of side friction.

\begin{tabular}{lcccc}
\hline Soil classification & Layer thickness $(\mathrm{m})$ & Measured value $(\mathrm{kPa})$ & Calculated value $(\mathrm{kPa})$ & 53 \\
\hline Loessial soil $\left(Q_{4}^{\mathrm{pl}}\right)$ & 6.5 & 54 & Error $(\%)$ \\
Old loess $\left(Q_{2}^{\text {eol }}\right)$ & 18.5 & 91 & 80 & 1.85 \\
\hline
\end{tabular}

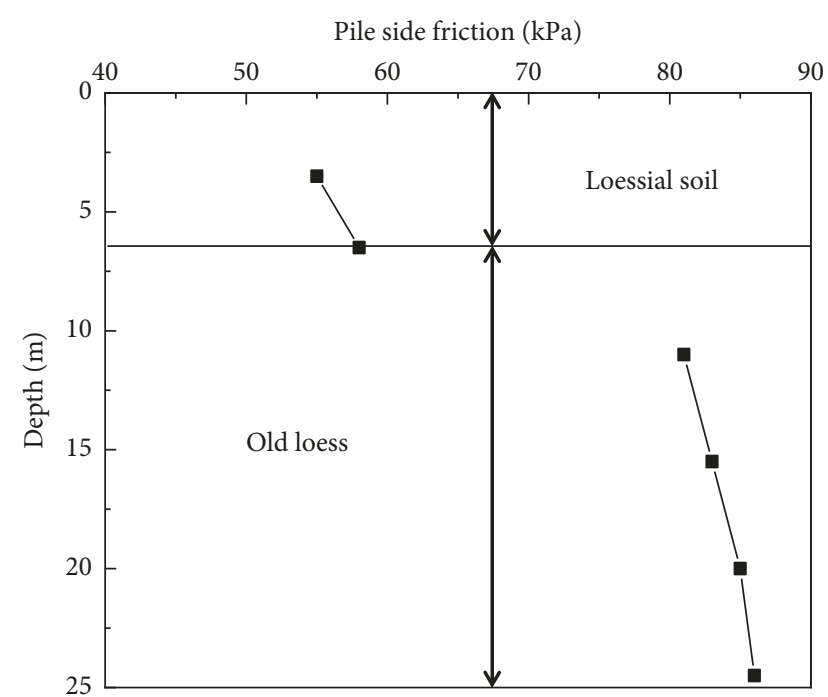

FIgure 10: The pile side friction along the pile depth.

parameters are reasonable, the calculation results of the multiparameter statistical analysis method can largely meet the engineering requirements.

When calculating pile side friction by the multiparameter statistical analysis method, without considering the change of shear strength index along the pile depth in the same soil, the average value of them is used to calculate pile side friction [40]. The calculation results are shown in Figure 10. It can be seen from Figure 10 that the pile side friction of the same soil layer varies little along the pile depth, while the pile side friction of different soil layers varies obviously along the pile depth. Therefore, in the multiparameter statistical analysis method, without considering the change of the shear strength index of the same soil layer along the pile depth, the pile side friction resistance of the same soil layer changes very little, while the shear strength index of different soil layers is different, and the pile side friction resistance of different soil layers changes obviously along the pile depth.

\section{Conclusions}

In this paper, static load testing was carried out on the six test piles, and the size and distribution of pile side friction was measured. Pile side friction in different soil layers was then calculated using the multiparameter statistical analysis method. The main findings are summarized as follows:

(1) The static load test results show that the pile side resistance and pile tip resistance are not entirely synchronized to the maximum. In the process of pile top load transfer, the resistance of pile side occurs prior to the resistance of the pile tip. As the loading continues to increase, the pile side resistance is fully exerted, the pile end resistance increases significantly, and the pile side frictional resistance first increases and then decreases from top to bottom.

(2) The multiparameter statistical analysis method based on the shear strength index can calculate the pile side friction of different soil layers in loess areas. If the parameters are reasonable, the error between the calculated value and the measured value of the static load test method can be controlled within $20 \%$.

(3) In the existing Chinese code [51], the value of pile side friction is determined by the type of pile and soil parameter index (void ratio and liquid index). This paper calculated pile side friction by the multiparameter statistical analysis method. It was found that pile side friction is related not only to the type of pile and soil parameter but also to the shear strength index.

\section{Data Availability}

The data used to support the findings of this study are available from the corresponding author upon request. 


\section{Conflicts of Interest}

The authors declare that there are no conflicts of interest regarding the publication of this paper.

\section{Acknowledgments}

This research was funded by the National Key R\&D Program of China (no. 2018YFC0808606) and the Project on Social Development of Shaanxi Provincial Science (nos. 2018SF378 and 2018SF-382).

\section{References}

[1] J. X. Lai, X. L. Wang, J. L. Qiu et al., "Extreme deformation characteristics and countermeasures for a tunnel in difficult grounds in southern Shaanxi, China," Environmental Earth Sciences, vol. 77, no. 19, pp. 1-14, 2018.

[2] J. Lai, J. Qiu, H. Fan et al., "Fiber bragg grating sensors-based in situ monitoring and safety assessment of loess tunnel," Journal of Sensors, vol. 2016, Article ID 8658290, 10 pages, 2016.

[3] Y. Zhang, Z. Song, X. Weng, and Y. Xie, “A new soil-water characteristic curve model for unsaturated loess based on wetting-induced pore deformation," Geofluids, vol. 2019, Article ID 5261985, 13 pages, 2019.

[4] P. F. Li, K. Y. Chen, F. Wang, and Z. Li, "An upper-bound analytical model of blow-out for a shallow tunnel in sand considering the partial failure within the face," Tunnelling and Underground Space Technology, vol. 91, pp. 1-12, 2019.

[5] Z. Zhou, J. Lei, S. Shi, and T. Liu, "Seismic response of aeolian sand high embankment slopes in shaking table tests," Applied Sciences, vol. 9, no. 8, p. 1677, 2019.

[6] Z. J. Zhou, C. N. Ren, G. J. Xu et al., "Dynamic failure mode and dynamic response of high slope using shaking table test," Shock and Vibration, vol. 2019, Article ID 4802740, 19 pages, 2019.

[7] L. M. Duan, Y. H. Zhang, and J. X. Lai, "Influence of ground temperature on shotcrete-to-rock adhesion in tunnels," Advances in Materials Science and Engineering, vol. 2019, Article ID 8709087, 12 pages, 2019.

[8] L. M. Duan, W. S. Lin, J. X. Lai, and P. Zhang, "Vibration characteristic of high-voltage tower influenced by adjacent tunnel blasting construction," Shock and Vibration, vol. 2019, Article ID 8520564, 16 pages, 2019.

[9] X. L. Luo, X. Meng, W. J. Gan, and Y. H. Chen, "Traffic data imputation algorithm based on improved low rank matrix decomposition," Journal of Sensors, vol. 2019, Article ID 7092713, 10 pages, 2019.

[10] X. Liu, Q. Fang, D. Zhang, and Z. Wang, "Behaviour of existing tunnel due to new tunnel construction below," Computers and Geotechnics, vol. 110, pp. 71-81, 2019.

[11] Q.-Q. Zhang, S.-W. Liu, S.-M. Zhang, J. Zhang, and K. Wang, "Simplified non-linear approaches for response of a single pile and pile groups considering progressive deformation of pilesoil system," Soils and Foundations, vol. 56, no. 3, pp. 473484, 2016.

[12] Q.-Q. Zhang and Z.-M. Zhang, "A simplified nonlinear approach for single pile settlement analysis," Canadian Geotechnical Journal, vol. 49, no. 11, pp. 1256-1266, 2012.

[13] X. B. Yue, Y. L. Xie, H. G. Zhang et al., "Study on geotechnical characteristics of marine soil at Hongkong-Zhuhai-Macao tunnel," Marine Georesources and Geotechnology, vol. 37, no. 8, pp. 1-12, 2019.
[14] X. L. Wang, J. X. Lai, R. Garnes, and Y. B. Luo, "Support system for tunnelling in squeezing ground of qingling-daba mountainous area: a case study from soft rock tunnels," Advances in Civil Engineering, vol. 2019, Article ID 8682535, 17 pages, 2019.

[15] Z.-F. Wang, S.-L. Shen, and G. Modoni, "Enhancing discharge of spoil to mitigate disturbance induced by horizontal jet grouting in clayey soil: theoretical model and application," Computers and Geotechnics, vol. 111, pp. 222-228, 2019.

[16] M. F. Chang and B. B. Broms, "Design of bored piles in residual soils based on field-performance data," Canadian Geotechnical Journal, vol. 28, no. 2, pp. 200-209, 1991.

[17] C. S. Chen and L. C. Hiew, "Performance of bored piles with different construction methods," Proceedings of the Institution of Civil Engineers-Geotechnical Engineering, vol. 159, no. 3, pp. 227-232, 2006.

[18] V. M. Mamonov, A. M. Dzagov, and P. M. Ermoshkin, "Bearing capacity of bored-cast-in-place piles made from concretes having different compositions," Soil Mechanics and Foundation Engineering, vol. 26, no. 1, pp. 1-6, 1989.

[19] A. M. Rybnikov, "Experimental investigations of bearing capacity of bored-cast-in-place tapered piles," Soil Mechanics and Foundation Engineering, vol. 27, no. 2, pp. 48-52, 1990.

[20] M. G. Zertsalov, M. V. Nikishkin, and I. N. Khokhlov, "On the calculation of bored piles under axial compressive loads in rocky soils," Soil Mechanics and Foundation Engineering, vol. 54, no. 3, pp. 143-149, 2017.

[21] Q. Zhang, Z. Zhang, F. Yu, and J. Liu, "Field performance of long bored piles within piled rafts," Proceedings of the Institution of Civil Engineers-Geotechnical Engineering, vol. 163, no. 6, pp. 293-305, 2010.

[22] N. F. Ismael, "Axial load tests on bored piles and pile groups in cemented sands," Journal of Geotechnical and Geoenvironmental Engineering, vol. 127, no. 9, pp. 766-773, 2001.

[23] J. Lai, H. Liu, J. Qiu, and J. Chen, "Settlement analysis of saturated tailings dam treated by CFG pile composite foundation," Advances in Materials Science and Engineering, vol. 2016, Article ID 7383762, 10 pages, 2016.

[24] Y. Lei, J.-F. Yin, Q.-N. Chen, and Y.-X. Liu, "Experimental study on the rock-socketed segment of pile and analysis of its load-bearing characteristics," Journal of Highway and Transportation Research and Development (English Edition), vol. 11, no. 3, pp. 54-61, 2017.

[25] R. Nazir, H. Moayedi, M. Mosallanezhad, and A. Tourtiz, "Appraisal of reliable skin friction variation in a bored pile," Proceedings of the Institution of Civil Engineers-Geotechnical Engineering, vol. 168, no. 1, pp. 75-86, 2015.

[26] C. W. W. Ng, T. L. Y. Yau, J. H. M. Li, and W. H. Tang, "Side resistance of large diameter bored piles socketed into decomposed rocks," Journal of Geotechnical and Geoenvironmental Engineering, vol. 127, no. 8, pp. 642-657, 2001.

[27] Z. J. Zhou, S. S. Zhu, X. Kong et al., "Optimization analysis of settlement parameters for postgrouting piles in loess area of Shaanxi, China," Advances in Civil Engineering, vol. 2019, Article ID 7085104, 11 pages, 2019.

[28] J. X. Lai, H. Q. Liu, J. L. Qiu et al., "Stress analysis of CFG pile composite foundation in consolidating saturated mine tailings dam," Advances in Materials Science and Engineering, vol. 2016, Article ID 3948754, 12 pages, 2016.

[29] J. D. Geddes, "Stresses in foundation soils due to vertical subsurface loading," Géotechnique, vol. 16, no. 3, pp. 231-255, 1966. 
[30] Y. Fang, Z. Chen, L. Tao et al., "Model tests on longitudinal surface settlement caused by shield tunnelling in sandy soil," Sustainable Cities and Society, vol. 47, article 101504, 2019.

[31] I. Said, V. De, and R. Frank, "Axisymmetric finite element analysis of pile loading tests," Computers and Geotechnics, vol. 36, no. 1-2, pp. 6-19, 2009.

[32] I. J. Johannessen and L. Bjerrum, "Measurement of the compression of a steel pile to rock due to settlement of the surrounding clay," in Proceedings of the 6th International Conference on Soil Mechanics and Foundation Engineering, pp. 261-264, Montreal, Canada, September 1965.

[33] B. H. Fellenius and B. B. Broms, "Negative skin friction for long piles driven in clay," in Proceedings of the 7th International Conference on Soil Mechanics and Foundation Engineering, pp. 93-98, Mexico City, Mexico, August 1969.

[34] M. H. Zhao, X. J. Zou, and Q. J. Liu, "Experimental study on vertical bearing capacity of large diameter and super long castin-place piles in Dongting Lake soft soil area," China Civil Engineering Journal, vol. 37, no. 10, pp. 63-67, 2004.

[35] C. F. Zhao, J. Li, Z. X. Qiu et al., "Experimental study on load transfer characteristics of large diameter and super long bored piles in guangdong area," Journal of Rock Mechanics and Engineering, vol. 34, no. 4, pp. 849-855, 2015.

[36] X. W. Wang, N. G. Yi, and S. P. Zhang, "Static loading test of the end-bearing pile under the side friction action," Applied Mechanics and Materials, vol. 353-356, pp. 974-978, 2013.

[37] Q.-Q. Zhang, Z.-M. Zhang, and S.-C. Li, "Investigation into skin friction of bored pile including influence of soil strength at pile base," Marine Georesources \& Geotechnology, vol. 31, no. 1, pp. 1-16, 2013.

[38] S.-C. Li, Q. Zhang, Q.-Q. Zhang, and L.-P. Li, "Field and theoretical study of the response of super-long bored pile subjected to compressive load," Marine Georesources \& Geotechnology, vol. 34, no. 1, pp. 71-78, 2014.

[39] Z. H. Chen and D. Z. Gao, "Finding the ultimate lateral friction of pile side layered soil by multi parameter optimal solution," Engineering Investigation, vol. 1988, no. 5, pp. 1520, 1988.

[40] X. M. Lou, C. F. Zhao, G. Chen et al., "Statistical analysis of parameters for calculating lateral friction of precast pile soft clay with shear strength index," Rock and Soil Mechanics, vol. 31, no. S2, pp. 354-359, 2010.

[41] Ministry of Transportation of the People's Republic of China, Technical Specification for Construction of Highway Bridges and Culverts JTG/T F50-2011, People's Transportation Publishing House, Beijing, China, 2011.

[42] Ministry of Housing and Urban-Rural Construction of the People's Republic of China, Technology Specification of Building Pile Foundation Testing JGJ 106-2014, China Architecture \& Building Press, Beijing, China, 2014.

[43] J. Qiu, Y. Qin, Z. Feng, L. Wang, and K. Wang, "Safety risks and protection measures for the city wall during the construction and operation of Xi'an metro," Journal of Performance of Constructed Facilities, vol. 33, no. 5, p. 12, 2019.

[44] C. F. Zhao, J. Lu, Q. C. Chao et al., "Experimental study on layered load transfer characteristics of large diameter and deep bored piles," Journal of Rock Mechanics and Engineering, vol. 28, no. 5, pp. 1020-1026, 2009.

[45] Ministry of Housing and Urban-Rural Construction of the People's Republic of China, Code for Design of Concrete Structures GB 50010-2010, China Architecture \& Building Press, Beijing, China, 2010.
[46] F. J. Chen, J. L. Ma, L. Zhu et al., "Analysis of pile side friction and pile end resistance of high speed railway bridges," Railway Engineering, vol. 6, pp. 41-43, 2013.

[47] Z. M. Zhang and Q. Q. Zhang, "Experimental study on the bearing behavior of post-grouting piles," Journal of Rock Mechanics and Engineering, vol. 28, no. 3, pp. 475-482, 2009.

[48] Z. M. Zhang, Q. Q. Zhang, and F. Yu, "A destructive field study on the behavior of piles under tension and compression," Journal of Zhejiang University-Science A, vol. 12, no. 4, pp. 291-300, 2011.

[49] Y. Q. Wang, H. T. Chang, J. Y. Wang, and X. L. Shi, "Countermeasures to prevent collapse during the construction of road tunnel in fault zone: a case study from the Yezhuping tunnel in South Qinling China," Environmental Earth Sciences, vol. 78, no. 606, pp. 1-14, 2019.

[50] Y. Zheng, J. Xiong, T. Liu, and X. Yue, "Performance of a deep excavation in Lanzhou strong permeable sandy gravel strata," Arabian Journal of Geosciences, vol. 12, no. 16, p. 12, 2019.

[51] Ministry of Construction of the People's Republic of China, Technical Specification for Building Pile Foundation JGJ942008, China Architecture \& Building Press, Beijing, China, 2008.

[52] Y. K. Hong, X. M. Lou, and Q. H. Chen, "Statistical analysis of vertical bearing capacity parameters of driven precast reinforced concrete piles," Journal of Geotechnical Engineering, vol. 15, no. 1, pp. 53-59, 1993. 


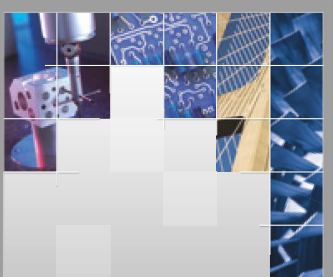

\section{Enfincering}
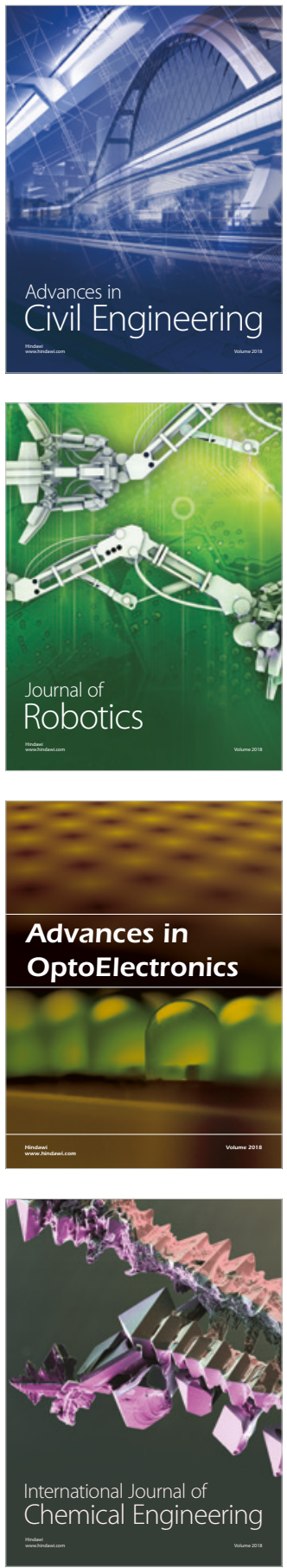

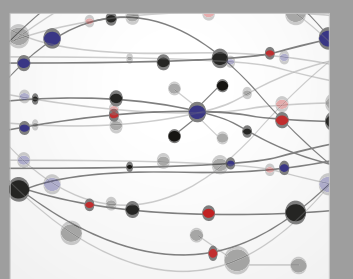

\section{Rotating \\ Machinery}

The Scientific World Journal

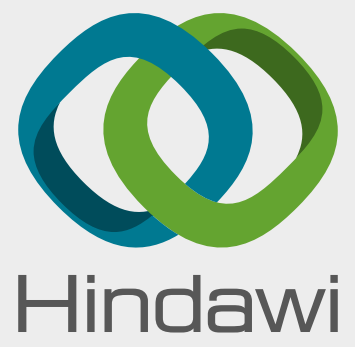

Submit your manuscripts at

www.hindawi.com
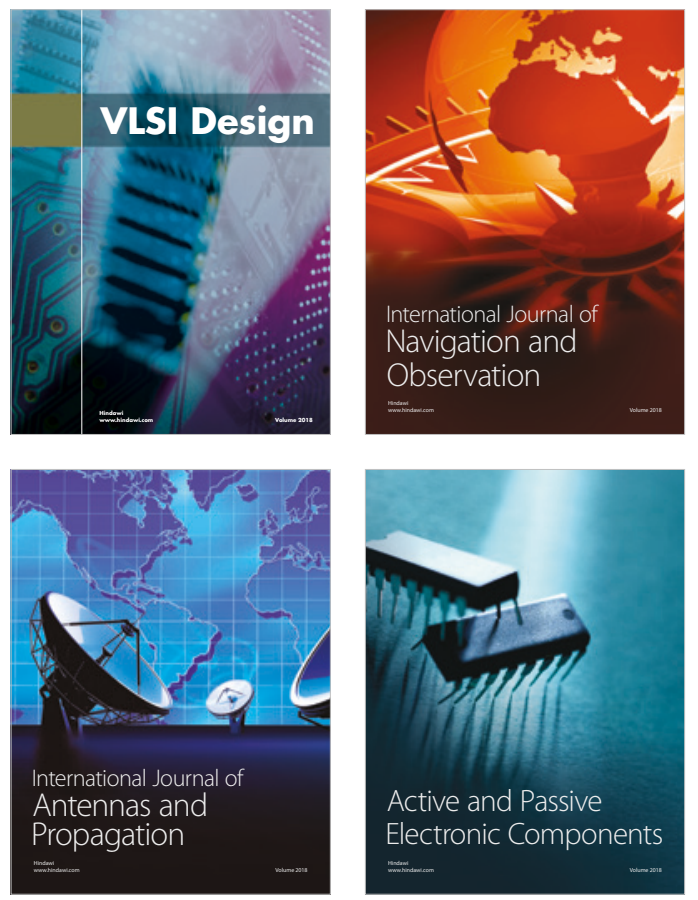
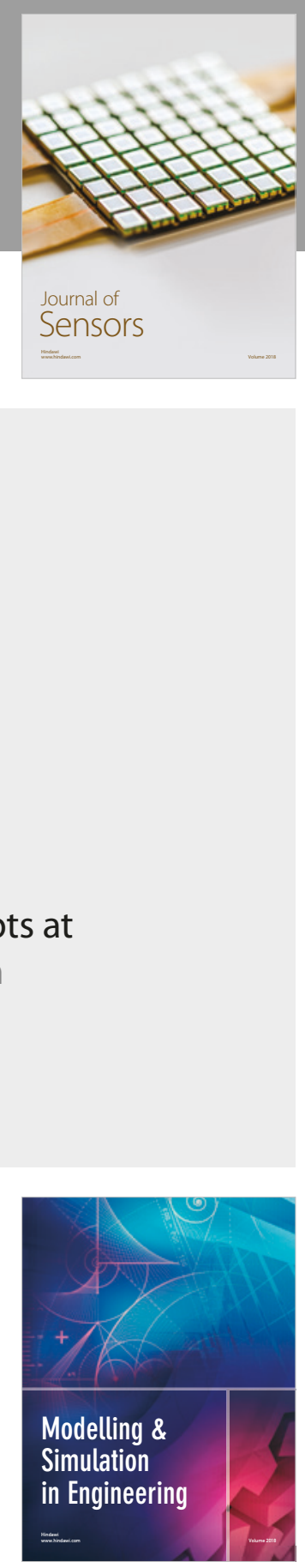

\section{Advances \\ Multimedia}
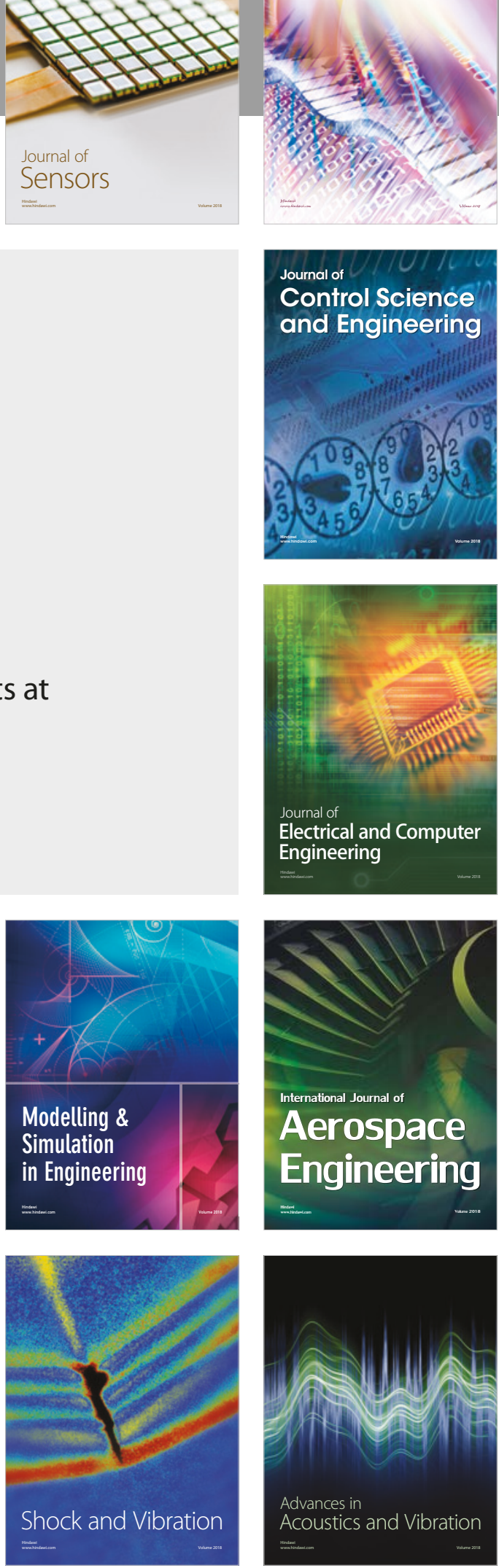